\title{
Negotiated Order: The Fourth Amendment, Telephone Surveillance, and Social Interactions, 1878-1968
}

\author{
Colin Agur
}

In the United States the words "telephone surveillance" bring to mind contemporary security concerns about smart phone tracking, the NSA warrantless wiretapping scandal, and the telecommunications provisions of the Patriot Act. Yet telephone surveillance is as old as telephony itself, dating back to the nearly simultaneous commercialization of the telephone and phonograph. This article examines telephone surveillance by American law enforcement agencies from the inception of telephone service to the passage of the Federal Wiretap Law in 1968, focusing on the challenges an advancing, proliferating, and shrinking technology posed for Fourth Amendment law. To highlight the technological, institutional, and cultural interactions that have shaped Fourth Amendment jurisprudence, the article deploys Jack Balkin's theory of cultural software and Anslem Strauss's concept of a negotiated order and brings together major cases, federal legislation, and evidence of government surveillance. The article argues that during the first ninety years of telephone usage in America, laws on search and seizure developed not from constitutional consistency or logic but as the result of a complex negotiation process involving new media and human agency.

Since the opening of the first telephone exchange in 1878, the recorder has maintained a close relationship with the telephone. Dating back to the two devices' nearly simultaneous market releases, this relationship has provided a unique and complex set of questions in Fourth Amendment law. These questions have inspired an academic literature that explores the political history of telephone surveillance, ${ }^{1}$ the case law of wiretapping, ${ }^{2}$ and the role of telecommunications in Fourth Amendment jurisprudence. ${ }^{3}$ These studies have identified the technological stories behind the law and highlighted the important actors in

Colin Agur is a PhD candidate in communications at Columbia University and a visiting fellow at Yale Law School's Information Society Project.

Information $\mathcal{E}^{2}$ Culture, Vol. 48, No. 4, 2013

(C)2013 by the University of Texas Press DOI: $10.7560 / \mathrm{IC} 48402$ 
the construction of the law. This article builds on this literature by emphasizing the cultural aspects of telephone surveillance and by treating surveillance laws as a negotiated order in American society. A study of negotiation requires a description of interaction, including the actors involved, the strategies and tactics they employ, and the outcomes of their actions. ${ }^{4}$

This article deploys the cultural software theory developed by Jack Balkin to show how a set of cultural tools (technologies, institutions, and cultural software) affected the design of laws governing telephone surveillance. ${ }^{5}$ Balkin's theory also allows for an analysis of individual agency in the formation of these laws. ${ }^{6}$ With the assistance of key actors, over time cultural software reshaped the fabric of the law. For Balkin, software is not a tool we deploy; rather, it is an essential part of our relationship with knowledge. ${ }^{7}$ An important part of cultural software is its relationship with history. Cultural software develops over time via a process of social interaction, as the arrival and adoption of new technology alter the rules in a society. ${ }^{8}$ Cultural software focuses on ideology as its object and breaks the study of ideology into studies of ideological mechanisms and effects. For Balkin, ideological thinking takes place when actors employ the ideological mechanisms of cultural software and produce ideological results. ${ }^{9}$

This theoretical framework allows for a study of the challenges that lawmakers and judges faced as they sought to reconcile the language of the Fourth Amendment, the politics and security concerns of the federal government, the civil liberties of telephone users, and the new technological reality brought about by covert recording devices. I show the roles that technologies, institutions, and cultural software each played in the negotiation of telephone surveillance law as telephone service expanded and became a vital communicative element in American culture. I also show how and why new communication devices, with new relationships to time and space, are often the focal points in societal negotiations on privacy. Putting to use the negotiation concepts developed by Anslem Strauss, I follow the negotiation of the law, as well as the changing negotiation and structural contexts in which these negotiations developed. ${ }^{10}$ By following the "middle level" methodology suggested by Thomas Misa, I focus on the actors, institutions, and processes intermediate between the macro and micro. ${ }^{11}$ With this theoretical framework, I show how influence runs in two directions: the consequences of negotiations can be measured in long-term structural changes, and structural contexts affect how individuals act. 


\section{The Origins of Telephone Surveillance}

The technological, institutional, and cultural aspects of telephone surveillance can be understood by studying the context in which they develop. This section begins with a discussion of telegraph surveillance, then describes the technological development of telephone surveillance, moves on to describe the culture of American police and politics in the early twentieth century, and concludes by identifying the critical role Prohibition played in the growth of telephone surveillance in the 1920s.

Telegraph surveillance developed significantly in the years during and after the Civil War. The conflict demonstrated the military advantages of messages sent by wire, as well as the risks of having messages intercepted by the opposing side. ${ }^{12}$ In the years following the war, telegraph technology improved, Western Union built a nationwide network, and telegrams became increasingly popular among journalists, investors, and political officials. ${ }^{13}$ Messages conveyed by wire often involved sensitive information, and the telegraph companies sought to protect the privacy of their customers. ${ }^{14}$

Two sets of forces made it difficult for telegraph companies to guarantee the privacy of their communications. The first involved the operational features of the telegraph: for telegrams to be transmitted, they would need to be written by a human telegraph operator and their contents made visible to a series of operators along the wire.$^{15}$ Another operational feature stemmed from the written nature of telegraphic communication: as a courtesy to their customers and to guard against the possibility of lost messages, telegraph companies kept a copy of each message on file. This allowed customers to retrieve past messages, but it also created a rich archive for those with access. The second set of forces was institutional: as telegraphic communication grew more popular in the late 1860 s and early 1870 s, Western Union attracted the attention of the federal government and faced frequent pressure to turn over its copies of messages. ${ }^{16}$ Battles between telegraph companies and the federal government continued through the 1870 s. ${ }^{17}$ In 1873 Western Union instructed its employees not to comply with subpoenas for telegrams. ${ }^{18}$ The disputed Hayes-Tilden election of 1876 resulted in Congress issuing subpoenas for telegraph records, in search of information that could resolve the electoral crisis. After a protracted legal fight, Western Union eventually delivered some thirty thousand telegrams to a Senate investigatory committee. ${ }^{19}$

While the federal government succeeded in seizing telegrams, it faced growing constraints on its ability to read the contents of letters sent by 
post. The decision in Ex parte Jackson extended Fourth Amendment protection to correspondence by the postal service. The decision stated in unambiguous terms that the legal protection of "papers" included letters sent via the post: "The constitutional guaranty of the right of the people to be secure against unreasonable searches and seizures extends to their papers, thus closed against inspection, wherever they may be." ${ }^{20}$ According to Anuj Desai, this decision was not the result of an inherent constitutional protection of communications but instead of the institutional culture of the postal service. ${ }^{21}$ Over time, administrative practices by the post office created a de facto legal principle that the Supreme Court recognized in Ex parte Jackson. The decision shows a disjuncture that had developed between communication by post, which remained private as per postal practice and the decision in Ex parte Jackson, and communication by telegraph, which was susceptible to raids by congressional investigations. ${ }^{22}$ It was into this context of legal disjuncture for communications that the telephone arrived. The unanswered question of privacy, combined with the new features of the telephone, shaped the institutional and cultural identity of the new device.

Like the telegraph, the telephone was initially a high-cost specialty service reserved for a business clientele. From the opening of the first exchange in 1878, the telephone suffered from some of the same privacy challenges that plagued the telegraph: the telephone required a network of physical hardware and personnel to convey messages from sender to receiver, and human operators knew who was calling whom and for how long. For surveillance, the telephone differed from the telegraph in two crucial respects: first, while telephone operators may have known who was calling whom, they did not know the contents of the conversations. Second, and more importantly, as a real-time, voice-to-voice technology, the telephone encouraged conversations. The telegraph had proven its worth as a rapid transmitter of short messages over long distances, but the telephone offered something new: the real-time nature of its communication, coupled with the difficulty of outsiders transcribing conversations, made the telephone ideal for planning crimes. These features drew criminals and investigators alike to the new device: "Telephone customers were far more likely to reveal their criminal plans into a telephone than they were to a telegraph operator. In order to use this new technology, customers did not have to go to an office and first communicate their messages to others who would then relay them to the recipient. Billing occurred at the end of the month, based on the time the telephone was used, not the number of syllables used. All these factors made telephone customers far less cautious in the words they 
chose." ${ }^{23}$ Thus the institutional and technological aspects of the telephone had a large effect on early telephone culture: flat-rate monthly billing, combined with the oral nature of the telephone, encouraged customers to discuss and elaborate more than they could have in telegrams. For investigators to make use of this information and connect it with other clues, they would need to have recordings of conversations.

Telephone recording was made possible by the adaptation of the phonograph's recording capacity to the telephone. Seeking to create a "conscientious and infallible scribe" to make permanent the otherwise ephemeral flow of conversation, Thomas Edison aimed his new device at businessmen interested more in putting oral contracts to paper than in open conversation. ${ }^{24}$ The initial phonograph was designed for customers who chose to record their own conversations. Edison had not intended the device as a tool for those seeking to surreptitiously record other parties, and it was not until the 1890s that recorders could be placed inside telephones to record conversations without the knowledge of the caller or receiver. ${ }^{25}$

Early wiretapping was cumbersome and dependent on technicians. The process involved opening the target's phone, installing a tap linking circuits together, and routing the audio signal to a recorder. Initial efforts were fraught with problems involving the clarity and volume of communication. Individual users held their phone handsets at different distances from their mouths; users' ways of speaking also had differences in pitch, speed, volume, and cadence of speech. These differences in users' habits meant that many transcriptions of early conversations were incomplete or unintelligible. Such recordings often provided police with scant clues, and the recordings' lack of clarity meant that they could not be entered into court as evidence. ${ }^{26}$

As wiretapping devices improved, so did the quality of recordings. Wiretapping became easier and more pervasive when direct tapping could be done from outside the target's home or office. Overhead telephone lines allowed the easiest point of access for phone tappers. By the early twentieth century, would-be tappers needed to know only the location of the target's drop loop and where it intersected with the terminal box. ${ }^{27}$ With this information, the tapper could install an extension line to a discreet location nearby. Early wiretapping efforts had sometimes produced giveaway signs to those in the know: unusually low volume on the call or a midconversation clicking sound.$^{28}$ As wiretapping devices improved, it became more difficult for users to determine whether their telephone had been tapped. By the 1920s the art of wiretapping had advanced to the point that those with the know-how-typically police, 
private investigators, and members of criminal organizations-had fairly easy access to the conversations of their targets. ${ }^{29}$

Telephone surveillance became a tool of investigation at a particular moment in American police history. During the first two decades of the twentieth century, support for police authority extended far beyond the confines of government chambers. As Wesley Oliver notes, "Progressives, exemplified by Teddy Roosevelt, convincingly made the case that honest police officers could be trusted to determine the appropriate use of potentially lethal force. Corruption, not power, was the fear of the Progressive Era." ${ }^{30}$ In this view, the modern police force, isolated from political meddling and equipped with the latest in technology, offered the first line of defense against public disorder. Police "encouraged the public to see them ... as the only group possessed with the knowledge and skills necessary to carry out law enforcement." ${ }^{31}$ When in 1916 it became public knowledge that New York City police used wiretaps in criminal investigations, the city's police commissioner, Arthur Woods, claimed that he and his officers were "sufficiently skilled at identifying criminals that innocent conversations would not be intercepted." ${ }^{32}$ In these early years, in part because of the limited spread of the telephone and in part because of public deference to police authority, police officers faced little risk of prosecution or discipline for wiretapping. ${ }^{33}$ Put to use by powerful big-city police forces, telephone surveillance emerged as a largely unregulated tool of protection and order in early twentiethcentury America.

In the 1910s two factors gave added significance to telephone surveillance. The first was institutional and technical: rapid network expansion brought more people's lives and businesses onto telephone lines, transforming what was once a high-end niche service into a mass medium. ${ }^{34}$ The second factor was political and cultural: with the passing of the Eighteenth Amendment and Volstead Act in 1919, the US government drove the production and sale of alcohol underground.$^{35}$ To enforce the now-illegal trade, police began to use wiretaps to gather evidence on bootleggers and their networks. ${ }^{36}$ Initially, Prohibition emboldened investigators: "For a time after the Volstead act went into effect . . . few persons, even among lawyers, conceived the idea of questioning any Federal Government agent's right to search for and seize contraband liquor as he felt inclined or as his suspicions directed. The agents themselves, and many of their superiors, felt secure in their right to do so as Government officials." ${ }^{37}$ Since the federal government had banned the possession of alcohol, the "mere evidence" rule made it easier for Prohibition agents to make seizures. Under "mere evidence," "an 
individual could claim no legitimate property interest in the fruits of a crime, such as: stolen goods; its instrumentalities, such as the knife used in the crime; or in contraband, such as illegal narcotics." 38 The enforcement of Prohibition caused a spike in the number of search warrants, as federal agents obtained permission to search for and seize illegal liquor. And with investigation in the hands of federal agents, Prohibition led to a corresponding spike in federal criminal cases. As Craig Lerner writes, "Long before the 'war on drugs,' the National Prohibition Act provided an engine for the expansion of federal criminal law enforcement." 39

As Prohibition unfolded, the telephone played a unique institutional role in its politics. Prohibition arrived as the telephone gained mass usage and connection quality improved. Consequently, telephone surveillance became more commonly practiced and a more valuable tool of investigation. Wesley Oliver describes how the politics of Progressivism allowed police to listen in to conversations with relative ease: "A police officer would simply go to the telephone company and request that the phone company assist them with a wiretap. The telephone company assumed that it was compelled ... to assist the police whenever an officer made a request. Later, as the telephone company grew concerned about these informal procedures, the police agreed that a written request, signed by the Commissioner of Police, would be provided to the telephone company when the police requested a wiretap." ${ }^{40}$

Prohibition ushered in two new institutional developments. First, rather than local police listening in, increasingly it was federal agents who tapped phones. ${ }^{41}$ Second, in place of the temporary and often informal surveillance that had been common in previous years, Prohibition brought the sustained and sanctioned use of wiretapping for evidence gathering. ${ }^{42}$ As Orin Kerr argues, Prohibition brought wiretapping and the Fourth Amendment into prominence: "Before Prohibition, the scope of the Fourth Amendment was rarely litigated. The Fourth Amendment regulated only the Federal government, not the states, and the Federal government brought only a few thousand criminal cases nationwide per year. As a result, the Supreme Court mentioned the Fourth Amendment in only about two dozen cases in the first 130 years of the Amendment's existence, and actually interpreted the Amendment only a handful of times in that period. None of those cases involved wiretapping. Indeed, no published federal criminal cases mentioned wiretapping before the Prohibition era." ${ }^{43}$

From 1919 onward, the Fourth Amendment gained new attention from lawyers, judges, and criminals. To enforce Prohibition, police and federal agents used the country's growing telephone networks for evidence gathering, prompting a series of criminal cases. ${ }^{44}$ 


\section{New Institutional Forces: The Courts, Congress, and the FBI}

Prohibition enabled the institutionalization of wiretapping. With telephone networks expanding and wiretapping devices becoming increasingly sophisticated, police and federal agents made significant use of telephone recordings in their pursuit of liquor producers and distributors. From the 1920s onward, telephone surveillance became a formalized element in investigations by big-city police forces, the FBI, and the Department of Justice. Telephone surveillance also became the subject of a major court case and federal legislation regulating communications practices. Prohibition served as a critical chapter in the history of the Fourth Amendment, creating new interactions among a growing set of participants in the negotiation process.

In 1928 the use of wiretapping to enforce Prohibition became the subject of a landmark case. During the 1920s Roy Olmstead, a former police officer, had run a highly profitable bootlegging operation out of a Seattle office. Over a period of several months, local police tapped Olmstead's lines using recorders in the basement of the building and in the terminal boxes down the street. ${ }^{45}$ The conversations revealed Olmstead to be a 50 percent partner in an operation with revenues of $\$ 2$ million per year. Police arrested Olmstead and several dozen associates and used the recordings to indict them on violations of the National Prohibition Act. ${ }^{46}$

Olmstead's lawyers appealed the conviction, and the case came before the Supreme Court. In a controversial 5-4 decision, the Court upheld the conviction and established the precedent that police wiretapping, conducted without physical entry onto the suspect's property, was constitutional and not in violation of any federal law. Writing for the majority, Chief Justice William Howard Taft argued that the Fourth Amendment "does not forbid what was done here. There was no searching. There was no seizure. The evidence was secured by the use of the sense of hearing and that only. There was no entry of the houses or offices of the defendants." ${ }^{47}$ For Taft, search and seizure required physical entry to the premises. Wiretapping devices made entry unnecessary, but Taft saw this as beside the point. Since the police had not entered Olmstead's office, there was no violation of his constitutional rights.

Taft's words reveal the challenge Olmstead presented for the Court as it interpreted the Fourth Amendment. Written in the late eighteenth century, the Fourth Amendment was not designed with the telephone or wiretapping in mind. Rather, it emphasized physical entry as the sole means to conduct a search, and it provided protection to citizens on 
that basis: "The right of the people to be secure in their persons, houses, papers, and effects, against unreasonable searches and seizures, shall not be violated, and no Warrants shall issue, but upon probable cause, supported by Oath or affirmation, and particularly describing the place to be searched, and the persons or things to be seized." In Olmstead the Court faced the task of applying the Fourth Amendment to a case in which the accused's premises had not been searched in any physical way, nor had any of his property been seized. In a literal, physical sense, Taft was correct: police remained outside Olmstead's office and home. Instead of entering, police had used a device that facilitated eavesdropping-a practice not mentioned in the Fourth Amendment. ${ }^{48}$ In the absence of legislation dealing specifically with telephone surveillance, Taft saw no reason to reenvision the Fourth Amendment in the new technological context. ${ }^{49}$ This case revealed how the arrival of telephony and covert recording devices created a new debate for interpreters of the Fourth Amendment: if it is possible to not merely eavesdrop but also record conversations, and if this can be done at a distance from the target's residence or office, does this change what it means to search and seize?

The case provoked a sharp division in the Court, with Justice Louis Brandeis offering the leading voice against Olmstead's conviction. In his dissent, Brandeis argued that the Fourth Amendment protected not only physical places but also intangibles, such as a conversation using devices that purported to offer the parties private communication. Brandeis had a special interest in technology and privacy and had previously called for a broad "right to privacy." In their Harvard Law Review article, published in 1890, Brandeis and Samuel Warren argued that "recent inventions and business methods call attention to the next step which must be taken for the protection of the person, and for securing to the individual ... the right "to be let alone." "50 Their notion of a right to be "let alone" was a reaction to new devices that had "invaded the sacred precincts of private and domestic life" and threatened to make public the "domestic occurrence" of private thought and communication. ${ }^{51}$

Photography and the tabloid press had prompted Warren and Brandeis to write their 1890 article; three decades later, everyday "domestic occurrences" were threatened by a new combination of devices: the telephone and wiretaps. In a draft of his dissent in Olmstead, Brandeis made reference not only to these but also to radio and the nascent technology of television. ${ }^{52}$ Drawing attention to these devices and to the possibility of future technological advances, Brandeis foresaw that physical barriers would offer declining protection of privacy. ${ }^{53}$ 
Brandeis also saw a danger in police using a new device to gain (what he saw as) ill-gotten evidence. He argued that by condoning warrantless wiretapping, the Court would weaken the public's respect for the law:

In a government of laws, existence of the government will be imperiled if it fails to observe the law scrupulously. Our government is the potent, the omnipresent teacher. For good or for ill, it teaches the whole people by its example. Crime is contagious. If the government becomes a lawbreaker, it breeds contempt for law; it invites every man to become a law unto himself; it invites anarchy. To declare that in the administration of the criminal law the end justifies the means-to declare that the government may commit crimes in order to secure the conviction of a private criminalwould bring terrible retribution. Against that pernicious doctrine this court should resolutely set its face. ${ }^{54}$

Brandeis argued that the law should be treated as a living thing to be interpreted by the courts within the technological context of the time. It was true that police had not entered Olmstead's house or office, and, according to a strict reading of the Fourth Amendment, he was not subject to an unlawful search or seizure. But for Brandeis the issue was how wiretapping gave police end runs around privacy and due process. If a new confluence of devices-in this case, the telephone, its network, and wiretaps-allowed governments to monitor communication within suspects' homes from outside, the courts had a responsibility to apply the new technological reality to old language about search and seizure. Just as police required a warrant to physically enter the home of a suspect, Brandeis argued, so too should they require a warrant to monitor communication within the premises, using wiretaps and other communication devices unforeseen when the Fourth Amendment was written.

The divisions on the Court foreshadowed some of the difficulties that lawmakers would later have when drafting legislation on telephone surveillance. One major difficulty involved the miniaturization of devices: as they became smaller, they also became more powerful and more difficult to detect. Another possibility was that governmental institutions might use telephone surveillance to make end runs around constitutional principles. Despite forceful dissents from Justices Brandeis, Harlan Stone, Oliver Wendell Holmes, and Pierce Butler, a bare majority upheld Olmstead's conviction and established the precedent that warrantless police wiretapping was constitutional and that evidence obtained from wiretapping was admissible in court..$^{55}$ 
In the years that followed Olmstead, the politics of telephone surveillance changed dramatically. Growing opposition to Prohibition led eventually to the repeal of the Eighteenth Amendment and to the dismantling of much of the investigative infrastructure used to enforce Prohibition. The removal of this legal and political framework undermined police departments' arguments that wiretapping was a necessary tool of investigation. Yet as the following years would reveal, new politics soon produced new justifications for telephone surveillance, and the legislation passed in subsequent years faced a new technological reality in which limits on surveillance were increasingly difficult to enforce.

A year after the repeal of the Eighteenth Amendment and six years after Olmstead, Congress passed the Communications Act of 1934. The act organized federal regulation of telegraph, telephone, and radio communications under the auspices of the new Federal Communications Commission. ${ }^{56}$ One short and seemingly innocuous section, section 605 , had significant implications for the legality of wiretapping. That section made clear that telephone companies had the responsibility to keep communications private unless law enforcement officials had followed due process and gained a warrant to intercept specific suspects' telephone communications. The new law required police to respect the legal constraints placed on telephone communications and instructed telephone companies to "establish appropriate policies and procedures for the supervision and control of [their] officers and employees." Moreover, it stipulated that common carriers must gain from police "appropriate authorization to activate interception of communications or access to call-identifying information" and, in the event that such authorization (namely, a warrant) did not exist, "prevent any such interception or access without such authorization." To track the use of wiretapping and prevent abuse by law enforcement officials, the act instructed common carriers to "maintain secure and accurate records of any interception or access with or without such authorization" and "to submit to the Commission the policies and procedures adopted to comply with the requirements established by the new law." The legislation empowered the FCC to review levels of compliance by common carriers and law enforcement agencies, impose penalties on offending law enforcement agencies and officials, and reimburse common carriers for costs-in equipment, facilities, or services-related to the provision of legitimate surveillance to law enforcement agencies. ${ }^{57}$

The Communications Act established what would henceforth constitute due process in wiretapping. Recognizing the pressure that law enforcement agencies could exert on common carriers, the act placed 
enforcement in the hands of a powerful new federal entity (the FCC), gave common carriers mechanisms by which they could voice complaints, and kept records of past wiretapping activities. Recognizing Taft's point that Olmstead's prosecution was constitutional because his premises had not been entered and because no existing law prohibited police from tapping Olmstead's phone, the Communications Act of 1934 filled a legal void. It acknowledged the validity of wiretapping by law enforcement agencies-to the exclusion of the general population, for whom wiretapping remained illegal—but set limits on the conditions under which wiretapping could be used. Moreover, the act recognized that despite their power over the general public, in practice, common carriers remained at the mercy of law enforcement agencies and of the local, state, and federal governments that directed these agencies. Six years after Olmstead, the Communications Act was a far-reaching effort to establish a national set of rules on telephone surveillance administered by the federal government. ${ }^{58}$ The Communications Act continued the trend, initiated during Prohibition, of the federal government taking the lead on telephone surveillance: the act gave a newly empowered federal agency a mandate to scrutinize police investigations, as well as the power to punish police departments that ran afoul of the new law.

In 1937 the Communications Act played a major role in a Supreme Court case that discussed the admissibility of evidence obtained by wiretapping. In Nardone v. United States, the Court was presented with a case whose defendants had been convicted of a series of liquor violations, based on evidence obtained by warrantless wiretaps. ${ }^{59}$ In its decision, the Court dismissed the evidence and overturned the convictions. Its ruling states that: "the plain words of $\S 605$ forbid anyone, unless authorized by the sender, to intercept a telephone message, and direct in equally clear language that 'no person' shall divulge or publish the message or its substance to 'any person.' To recite the contents of the message in testimony before a court is to divulge the message. The conclusion that the act forbids such testimony seems to us unshaken by the government's arguments." ${ }^{00}$

The decision in Nardone contained a curious ambiguity. On the one hand, it reaffirmed the Communications Act's provision that wiretapping should serve as an exception, undertaken with due process, rather than a norm in everyday police work. On the other hand, the decision did nothing to make wiretapping itself illegal; so long as police did not bring forward evidence based on warrantless surveillance, they remained within the bounds of the law. ${ }^{61}$

In its decision in Nardone, the Court weighed in on the wider debate regarding wiretapping and privacy in telephone communications. In the 
majority opinion, Justice Owen Roberts wrote: "For years, controversy has raged with respect to the morality of the practice of wiretapping by officers to obtain evidence. It has been the view of many that the practice involves a grave wrong. ... We think another well recognized principle leads to the application of the statute as it is written so as to include within its sweep federal officers, as well as others. That principle is that the sovereign is embraced by general words of a statute intended to prevent injury and wrong." 62 The Court took pains to note the importance of police work and the ways that criminal investigations pose unique dilemmas for the Fourth Amendment. Yet it rejected the argument that law enforcement officials could operate beyond the reach of the Communications Act. When drafting the sections of the act pertaining to wiretapping, Congress gave no special opt-out for investigators at the federal, state, or local level. Rather than emphasizing the process of investigation, section 605 prioritized the rights of common carriers to convey messages in private, without government intrusion.

The decision in Nardone reveals the growing significance for investigation that the telephone and telephone surveillance had taken on in the years since Olmstead. During those years, Congress had formulated not just robust legislation on wiretapping but also a wider philosophy on how telephone surveillance related to personal liberty. Meanwhile, the Supreme Court had recognized how wiretapping prompted concerns about the Fourth Amendment and refused to accept the admissibility of recordings obtained by law enforcement agencies without the due process of a warrant. This is a significant progression. In 1928 the Court (narrowly) upheld Olmstead's conviction in large part because of the absence of legislation pertaining specifically to wiretapping; the Court had struggled with how the Fourth Amendment should deal with devices whose power lay in their ability to transcend the physicality of search. In 1937 the Court had the Communications Act as the legislative basis for its decision plus the hindsight of discussion in Olmstead. While Nardone left unclear what limits (if any) applied to law enforcement agencies' use of telephone surveillance, the decision in Nardone provided a precedent for how the Court would treat evidence gained via warrantless wiretaps.

The late 1930s and early 1940s brought a new political context for federal telephone surveillance. Federal prosecutors, politicians, and newspapers focused their attention on organized crime syndicates operating across state lines. ${ }^{63}$ Eager to build the bureau's credentials and power, FBI Director J. Edgar Hoover authorized extensive use of covert, unwarranted wiretapping. Evidence has since emerged that FBI wiretapping extended far beyond the needs of criminal investigation; 
it became a political tool used by the agency in its battles with officials of other government agencies, members of Congress, and even justices of the Supreme Court, whose conversations were recorded and used to intimidate them. ${ }^{64}$ The FBI was hardly alone in its appetite for wiretapping: as a congressional report would later reveal, the Department of Treasury installed more than ten thousand warrantless taps between 1934 and 1948. ${ }^{65}$ These are the verified instances from the Department of Treasury alone; while this figure likely represents a fraction of the total, it provides some sense of the routinization of wiretapping in the federal government. ${ }^{66}$

In the 1930s wiretapping practice by law enforcement agencies continued to grow and gain sophistication, despite a tightening set of laws and court decisions on the use of telephone surveillance. Two interrelated factors explain the growth of telephone surveillance during this period. The first is network expansion: with more and more Americans, including criminal syndicates, using telephones, the federal government invested in hardware and techniques to monitor telephone communications. A second factor was institutional politics: in its efforts to enforce Prohibition and, later, organized crime, the federal government concentrated and strengthened investigative powers in Washington, DC. With the telephone an increasingly common presence and the federal government increasingly the locus of criminal investigation, the telephone became woven into the investigative and security apparatus of the federal government. In this new context, certain individuals in government-none more than J. Edgar Hoover-made wiretapping both a normalized, quotidian practice by American law enforcement agencies and a weapon against enemies (real and imagined) of the American government. As a result of these developments, wiretapping became a sophisticated and shadowy business. Before the United States entered World War II, it had developed a powerful, centralized infrastructure for telephone surveillance. Whatever the contents of the law, if police or federal agents were willing to tap phones and clever enough to cover their tracks, there was no way to know for sure how many phones were tapped or who had access to the taped conversations. ${ }^{67}$

\section{Institutions and Actors in a Vital Mode of Communications}

In the years following the Second World War, telephone surveillance involved a new set of negotiations. As had been the case before the war, governmental institutions played major roles. In the postwar years, telephone surveillance became integrated into the Cold War security 
apparatus of the United States. The Washington, DC, area became the world's largest hub for telephone communications and the home base for a growing array of defense and security agencies. ${ }^{68}$ This clustering of intelligence and telecommunications infrastructure created an unprecedented governmental capacity for telephone surveillance, which the federal government put to extensive and often politicized uses: a 1985 congressional report on wiretapping and civil liberties found that "during and after World War II, the FBI engaged in large amounts of electronic surveillance. Between 1940 and 1960, the FBI installed over 7,000 national security surveillances," some of which involved large numbers of wiretaps on US citizens. ${ }^{69}$ The same report found that "other Federal agencies, like the military, also engaged in tapping and bugging." 70 Warrantless federal surveillance extended beyond security and "targeted many people who might not normally appear to be appropriate targets." 71 In the 1950s and early 1960s a distinctly Cold War American paradox emerged: the federal government claimed the right to listen in on foreign conversations, yet its own legislation specifically prohibited it from listening in (without a warrant) on its own citizens' conversations. ${ }^{72}$ As stakes grew in the Cold War, so did the investigative primacy and surveillance capacity of the federal government. The FBI and Justice and Treasury Departments grew in size and scope, and the executive branch of government claimed new authority over national security. ${ }^{73}$ With a more expansive federal government and the politics of the Cold War as backdrop, the postwar period saw the development of well-funded specialized security agencies that found new reasons to justify telephone surveillance. ${ }^{74}$

The growth of telephone surveillance as a security tool sat uneasily with the role played by the telephone in a prosperous and free society. ${ }^{75}$ The growing social and cultural role of the telephone prompted a new question: How effectively could Congress or the Supreme Court protect citizens from police or government abuse of telephone surveillance? The year 1967 brought two major cases involving wiretapping and Fourth Amendment law. These cases brought new limits on how extensively police could use wiretapping in individual instances and curtailed their ability to introduce recorded conversations as evidence in court.

The first of these cases, Berger $v$. New York, concerned how extensively police could use wiretaps on criminal suspects. With permission from the New York State Supreme Court, police installed a tap on Ralph Berger's office telephone. During the time in which Berger's phone calls were recorded, police found evidence that he had attempted to bribe the chairman of the New York State Liquor Authority to obtain 
a liquor license. On the basis of this evidence, Berger was arrested and indicted for conspiracy to commit bribery. His lawyers appealed, not on the grounds that the evidence was lacking or debatable (indeed, it was clear and irrefutable) nor on the grounds that police lacked probable cause for the tap (which the state supreme court had authorized). Instead, Berger's lawyers argued that the New York statute was too broad and that it allowed police to use wiretaps for general evidence gathering. Berger's lawyers argued that the statute systemized surveillance, authorized "general searches" for "mere evidence," and violated the privilege against self-incrimination. ${ }^{76}$ The Supreme Court found that "the language of New York's statute is too broad in its sweep, resulting in a trespassory intrusion into a constitutionally protected area, and is, therefore, violative of the Fourth and Fourteenth Amendments." ${ }^{\text {77 }}$ In a 6-3 decision, the Court overturned Berger's conviction and struck down the New York statute. ${ }^{78}$

A second case in 1967 placed further limits on how and when police could record telephone conversations. In Katz v. United States the FBI recorded conversations on a public pay phone in a high-crime neighborhood in Los Angeles. The recording functioned as a dragnet set up to give the FBI clues about unsolved crimes. In 1967 Charles Katz-who had been known to police as a suspect in illegal gambling cases-stepped into an enclosed public pay phone and closed the door behind him. He placed a series of calls to bookies in Miami and Boston and made bets on sporting matches. These conversations were recorded with a device the FBI had installed on the roof of the phone booth. This detail is important: the FBI did not tap the phone but instead used a recording device to make a tape of Katz's side of the conversation. Based on recordings of these calls, Katz was arrested and convicted of illegal gambling. Katz's lawyers took the case to the Supreme Court on grounds of a Fourth Amendment violation. As in Olmstead, prosecutors argued that since the FBI had not physically entered the premises (the phone booth), they had not violated Katz's right to protection from search and seizure.

But 1967 presented a different legal and political context: the telephone had taken on a substantially larger role in American life, and the Warren Court had expanded civil liberties, due process, and the rights of defendants. Nearly two decades before Katz, Justice Felix Frankfurter had argued that with the proliferation of telephones, the reach of wiretapping extended well beyond "sordid little cases" and "not very nice people." ${ }^{.79}$ In the Katz decision, the Court went a step further: the majority opinion, written by Justice Potter Stewart, recognized the sanctity of individuals' privacy in a public phone booth: 
No less than an individual in a business office, in a friend's apartment, or in a taxicab, a person in a telephone booth may rely upon the protection of the Fourth Amendment. One who occupies it, shuts the door behind him, and pays the toll that permits him to place a call is surely entitled to assume that the words he utters into the mouthpiece will not be broadcast to the world. To read the Constitution more narrowly is to ignore the vital role that the public telephone has come to play in private communication. ${ }^{80}$

By taking this view, the Court saw privacy through the lens of the individual being recorded. In a 7-1 decision, the Court overturned Katz's conviction on the basis that police had violated the privacy a telephone booth was designed to provide and had thus conducted an illegal search. ${ }^{81}$

The Court also overturned the "trespass" doctrine, which had, since Olmstead, treated search and seizure in terms of physical entry. In an important contribution to Fourth Amendment jurisprudence, Justice Harlan argued that the law should protect a "reasonable" expectation of privacy. He wrote: "As the Court's opinion states, "the Fourth Amendment protects people, not places.' The question, however, is what protection it affords to those people. Generally, as here, the answer to that question requires reference to a 'place.' My understanding of the rule that has emerged from prior decisions is that there is a twofold requirement, first that a person have exhibited an actual (subjective) expectation of privacy and, second, that the expectation be one that society is prepared to recognize as 'reasonable.'" ${ }^{82}$ By focusing on citizens' expectations, Harlan introduced a legal concept of privacy that can evolve with changing technology and changing cultural assumptions about privacy. This concept altered the terms of debate: henceforth, the law would be defined by what citizens could reasonably expect, based on their knowledge of a particular physical space (in this case, a phone booth with doors that could be closed) and the sophistication of recording devices available at a given point in time. And when forming expectations about what degree of privacy to expect, citizens could include not only tangible items (such as papers and personal effects) but also oral statements made on public pay phones.

Forty-five years after Katz, Fourth Amendment scholars continue to debate its legacy. Many scholars argue that Katz reshaped search and seizure law by weakening the previous property-centric view of the Fourth Amendment. Anthony Amsterdam calls the case a "watershed in Fourth Amendment jurisprudence." ${ }^{83}$ James Tomkovicz describes Katz as a revolution in privacy. ${ }^{84}$ Richard Wilkins writes that "Katz revolutionized Fourth Amendment search analysis." ${ }^{85}$ Peter Swire states that Katz 
"struck down the earlier regime of property rules" and that the case has stood "as a bulwark against wiretaps and other emerging forms of surveillance." ${ }^{86}$ Other scholars have pointed more generally to the ways that Katz reshaped citizens' relationship with telecommunications. ${ }^{87}$ But one thing that Katz did not do was install a broad, Brandeisian notion of privacy for all Americans. Rather, the Court decision in Katz leaves privacy in the hands of state governments:

The Fourth Amendment cannot be translated into a general constitutional "right to privacy." That Amendment protects individual privacy against certain kinds of governmental intrusion, but its protections go further, and often have nothing to do with privacy at all. Other provisions of the Constitution protect personal privacy from other forms of governmental invasion. But the protection of a person's general right to privacy-his right to be let alone by other people-is, like the protection of his property and of his very life, left largely to the law of the individual States. ${ }^{88}$

The decision in Katz was not the sort of sweeping defense of privacy that Warren and Brandeis had called for in their famous article, "The Right to Privacy." 89 Rather than granting citizens a "right to be let alone," Katz allowed for continued use of the telephone for surveillance, albeit with rules. In this sense, we see the limitations of Katz. Certainly, the decision had symbolic value: it recognized the "vital" role telephony had come to play in American society, as well as the threat posed by telephone surveillance if public pay phones could be used as surveillance dragnets. It also provided a concept of privacy from the user's perspective. But given the ubiquity of the telephone and the ease of conducting telephone surveillance, no single decision was likely to significantly curtail surveillance as an investigatory practice. With this in mind, Kerr argues that "the Katz revolution proved a revolution more on paper than in practice." 90

Rather than revolutionize privacy law with respect to communication technology, Berger and Katz showed that such privacy depends as much on legislation as it does on constitutional protection. As Justice White noted in his dissent in Berger, in 1967 Congress was in the midst of "extensive hearings" on telephone surveillance, and the Court's decision would have "a substantial impact on the . . legislative consideration of these issues." 91 Meanwhile, President Johnson's Crime Commission had grown frustrated with the "intolerable" law on telephone surveillance, noting that the existing law was simultaneously overprotective and 
underprotective. ${ }^{92}$ It advised that "any congressional action should await the outcome" of Berger. ${ }^{93}$ When we situate the decision in this political context, we see that the Supreme Court was not alone in its concern. So great was the social and legal significance of the telephone in the late 1960s that all three branches of government found themselves wrestling with the implications of telephone surveillance. More than that, the various branches sought to influence each other: as Kerr notes, "far from being sui generis constitutional developments, the major constitutional decisions in Berger and Katz were carefully timed to influence the shape of statutory law. The Court was eyeing Congress, and decided both Berger and Katz with Congress in mind." 94 This interplay shows the importance key actors placed on telephone surveillance in the late 1960s; it also shows the scale and complexity of the negotiation process.

A year after the decisions in Berger (on wiretapping) and Katz (on bugging), Congress passed the Federal Wiretap Law of 1968 as Title III of the massive Omnibus Crime Control and Safe Streets Act. The Senate report that accompanied the new law makes clear that Congress took its cues from these cases:

Title III prohibits all wiretapping and electronic surveillance by persons other than duly authorized law enforcement officials engaged in the investigations of specified types of major crimes after obtaining a court order, with exceptions provided for interceptions by employees of communications facilities whose normal course of employment would make necessary such interception, personnel of the Federal Communications Commission in the normal course of employment, and government agents to secure information under the powers of the President to protect the national security. This proposed legislation conforms to the constitutional standards set out in Berger v. New York, 388 U.S. 41 (1967), and Katz v. United States, 389 U.S. 347 (1967). ${ }^{95}$

This new law provided a comprehensive set of rules on telephone surveillance, imposing clear limits on the conditions under which it is legal to listen to and record conversations surreptitiously. From a Brandeisian perspective, the Federal Wiretap Act disappoints, since the act's underlying assumption is that law enforcement agencies have a right to conduct electronic surveillance for investigation and crime prevention. Instead of giving unambiguous priority to individual privacy, the Federal Wiretap Act sought to balance the social and cultural role of the telephone with the investigative role of telephone surveillance. 
This legal compromise was the result of a long-running interactive process dating back to the late nineteenth century. The following section explores this process as a negotiation involving American technology, institutions, and culture and shows that individual agency played a critical role in this negotiation process.

\section{Discussion: Technologies, Institutions, Cultural Software, and Actors}

By examining telephone history from the inception of service to the decision in Katz, we can identify a set of interactions that eventually produced a legal order governing telephone surveillance. In this effort, we are assisted by Balkin's theory of cultural software, which identifies the multiple cultural tools that affect the design of rules in society. The theory helps us see the law as dynamic and experience based: the law develops and evolves within an "economy of exchange" involving technological, institutional, and cultural interactions. ${ }^{96}$ The interactions that produced laws on telephone surveillance show why the telephone has played such an important role in Fourth Amendment jurisprudence. By studying these interactions, we also encounter two advantages the Fourth Amendment offers for our understanding of the law. First, its relative lack of doctrine allows us to see the role of negotiations in the development of laws. Second, these negotiations help us understand the role of ideology in jurisprudence. The decision in Ex parte Jackson is crucial here: the Court turned a preexisting practice and ideology (the privacy of mail) into legal precedent and the basis for future decisions.

A large part of the negotiation of Fourth Amendment law has involved what constitutes a "search" or a "seizure" in a changing technological context. Part of the challenge lies in the Fourth Amendment's lack of clarity on warrants. As Thomas Y. Davies writes, "Largely because of this silence in the text, the need for warrants has been the central issue in the modern debate regarding search and seizure authority." 97 Prior to the telephone and Prohibition, this omission had not posed significant problems for communication technology; for more than a century the Fourth Amendment remained largely unlitigated and its scope largely unchallenged. But as the telephone became a critical tool of investigation for Prohibition and organized crime, it gave new prominence to the concepts of "search" and "seizure." Initially, the Supreme Court attempted to deal with the new technology using an old paradigm. In Olmstead the Court judged wiretapping on its physical qualities: Did police enter Olmstead's office or home? Did they seize 
any of his correspondence? The decision in Olmstead was that of a court with limited tools at its disposal: in the absence of a constitutional amendment prohibiting eavesdropping or specific legislation barring police from tapping a phone from outside, the Court deemed such action constitutional.

The decision in Olmstead proved to be a key moment in the negotiation of the Fourth Amendment. As Brandeis foresaw, future communication devices would further erode the protection citizens once enjoyed behind closed doors. Brandeis was right to argue that telephone surveillance required the Court to think differently about search and seizure, and his dissenting opinion in Olmstead remains an eloquent piece of judicial foresight. Advances in communications devices made them more powerful, smaller, and harder to detect. These advances also presented a conceptual problem for traditional physical notions of "search" and "seizure." During the years between Olmstead and Katz, telephone surveillance became both more sophisticated and more pervasive in response to the growth of telephone communications in American society. As the Supreme Court recognized in 1967, the "telephone" that featured in Olmstead was not the same "telephone" that the Court discussed in Katz. It was different not only in a technical sense but also, and more importantly, in a social sense: by the time of Katz, the telephone had become an indispensable carrier of American culture and an essential component in the federal government's security apparatus. This development was the result of actions by practitionerstelephone executives, engineers, lawmakers, judges, and users-who built the networks, established the rules, and made both expected and unexpected uses of the telephone.

The interaction between the telephone and the Fourth Amendment deepened in the postwar era thanks to a combination of technological, institutional, and cultural factors. With the emergence of improved connections and universal service, the telephone invited more frequent and longer conversations by its users. The continued use of flat-rate billing, coupled with the ubiquitous presence of telephones in businesses, houses, hotels, and phone booths, allowed the telephone to play a role unimagined in the 1870s: initially a high-end niche service for a rarefied group of businessmen, it evolved into a medium for gossip, idle chitchat, and intimate discussions between friends. Unlike telegrams, which could be carefully wordsmithed or encrypted to hide their true meanings, conversations on the telephone involved real-time communication among the parties. As many a victim of wiretapping would learn the hard way, the telephone had a natural sense of intimacy: even otherwise 
disciplined criminals were often startled by the candid-and incriminating - things they were caught saying into a handset. While telephone surveillance became easier to perform and more difficult to detect, the vast majority of users' conversations were of little interest to police or to the switchboard operators or other users who could hear conversations on party lines. Thus the "privacy" that telephone users expected was closely tied to the ubiquity of the device and a corresponding anonymity for users. As the telephone became a quotidian communicative feature of American life, investigators faced a new challenge: finding conversations involving criminal activity among the millions of calls placed daily.

The susceptibility of the Fourth Amendment to changes in communication devices has prompted intense scholarly debate about what, precisely, the Fourth Amendment protects. According to Wayne LaFave, "No area of the law has more bedeviled the judiciary, from the Justices of the Supreme Court down to the magistrate." ${ }^{98}$ Pointing to its hundreds of seemingly unrelated rules and absence of clear principles, scholars have called the Fourth Amendment "an embarrassment," "99 "a mess,"100 and "a mass of contradictions." 101 Silas Wasserstrom and Michael Seidman argue that Fourth Amendment law involves "a series of inconsistent and bizarre results that [the Supreme Court] has left entirely undefended." 102 Legal scholars have offered no shortage of prescriptions on how to improve search and seizure law. Jed Rubenfeld argues that "Fourth Amendment law should stop trying to protect privacy" and should instead emphasize "a right to security." 103 Daniel J. Solove argues that the notion of a reasonable expectation of privacy should be replaced with a "pragmatic" study of which government practices should be regulated, how, and to what extent. ${ }^{104}$ Supreme Court justices have also expressed frustration with Fourth Amendment jurisprudence. In the understated words of Felix Frankfurter, "the course of true law pertaining to searches and seizures ... has not ... run smooth." 105 Antonin Scalia is more explicit: complaining about the tendency of search and seizure cases to involve endless variations, he has stated, "I just hate Fourth Amendment cases." 106

These criticisms capture what many legal scholars see as a lack of consistency or logic in the Fourth Amendment. But there is another way of looking at this "problem": Fourth Amendment jurisprudence has a long history of negotiation, dating back to decisions by postal administrators to protect the contents of the mail and the Supreme Court's subsequent codification of that practice as a legal norm. ${ }^{107}$ In the post and in subsequent modes of communication, the degree of privacy enjoyed by users was determined not by clear direction from the Constitution nor 
by a consistent logic but instead by an often messy set of interactions. To paraphrase the words of Justice Oliver Wendell Holmes, the life of the Fourth Amendment has not been logic; it has been experience. ${ }^{108}$ This experience has involved a set of human agents whose decisions-in postal privacy, telephone policy and pricing, police practices, legal interpretations, and day-to-day use-created a set of norms in telephone communication. Their differing actions help explain the fragmented nature of Fourth Amendment jurisprudence and the limited ability of the courts to impose a broad right to privacy.

\section{Conclusion}

Today, with new communication devices raising some of the same questions the telephone raised about surveillance, some scholars are convinced that heroic judicial decisions are our best hope. For example, Lawrence Lessig has pointed to Brandeis's dissent in Olmstead as a model for Fourth Amendment jurisprudence amid technological change. ${ }^{109}$ Lessig is right to laud Brandeis for his prescience on how changes in communication technology would affect Fourth Amendment jurisprudence. But any such praise must be tempered with recognition of the courts' limitations in search and seizure law.

When new surveillance devices proliferate and evolve, the courts can offer only so much protection. Judicial boldness is attractive at first glance, but a bad ruling can hinder legislative solutions for decades. Cass Sunstein has argued for judicial caution in cases involving changing technology, noting that legislatures offer democratic political judgment. ${ }^{110}$ Legislative bodies have significant intellectual resources at their disposal and are able to move more proactively and nimbly than courts. ${ }^{111}$ Thus, instead of hoping that the courts break tradition and champion a broad, national "right to privacy," we could turn our attention to legislation. And while it may disappoint some, the solution-as suggested in Katz-may be robust legislation at the state level. One of the benefits of federalism is the experimentation it allows by state governments; as communication devices continue to shrink, converge, and develop new capacities, states serve as policy laboratories and a collective check on the actions of the federal government. To take such a position is not to abandon hope of protecting privacy. Rather, it is to recognize the room to move that states enjoy and the wisdom of the decision in Katz.

For researchers of telecommunications and the law, the history of telephone surveillance offers important lessons. In telephone surveillance 
we see how decisions by actors gave a device a particular social meaning and how that meaning evolved over time and space thanks to an ongoing negotiation process among the key actors. Human agency played a significant role in the formation of rules on telephone surveillance, and the social organization that emerged in the late 1960s was the result of a long-term negotiation involving a wide range of participants. Thus, rather than a case of a technology determining or (in the words of Thomas Hughes) giving "momentum" to a set of social changes, ${ }^{112}$ the jurisprudence governing telephone surveillance has been constructed by those who were able to establish practices and norms in telephony. In our efforts to understand the negotiation of telephone surveillance law and Fourth Amendment jurisprudence, Balkin's theory of cultural software serves us well. By examining a long-term economy of exchange involving technological, institutional, and cultural inputs, we can understand the social organization of the law. And by focusing on the negotiations and contexts in which they took place, we can understand the role of ideology in institutional practices, Supreme Court decisions, and legislation. At the same time, the history of telephone surveillance law helps us see the limitations of ideology and the importance of human agency. The actions of key agents, from engineers to administrators to lawmakers to judges, each contributed to ideology, which in turn shaped the evolution of Fourth Amendment jurisprudence.

\section{Notes}

The author wishes to thank Richard R. John, Anuj Desai, William Aspray, George Royer, Valerie Belair-Gagnon, and two anonymous reviewers for comments on earlier drafts. Thanks also to audiences at Yale Law School and City University London for providing feedback on some of the material in this article.

1. For example, see Samuel Dash et al., The Eavesdroppers (New Brunswick, NJ: Rutgers University Press, 1959); Alexander Charns, Cloak and Gavel: FBI Wiretaps, Bugs, Informers, and the Supreme Court (Champaign: University of Illinois Press, 1992); Mickie Edwardson, "James Lawrence Fly, the FBI, and Wiretapping," Historian 61, no. 2 (1999): 361-82; Wesley MacNeil Oliver, "America's First Wiretapping Controversy in Context and as Context," Hamline Law Review 34, no. 2 (2011): 205-61.

2. For example, see Peter P. Swire, "Katz Is Dead. Long Live Katz," Michigan Law Review 102, no. 5 (2004): 904-32; Robert Post, "Federalism, Positive Law, and the Emergence of the American Administrative State: Prohibition in the Taft Court Era," William and Mary Law Review 48, no. 1 (2006): 1-181; Carol S. Steiker, "Brandeis in Olmstead: 'Our Government Is the Potent, the Omnipresent Teacher,'” Mississippi Law Journal, Fall 2009, 149-78.

3. For example, see James J. Tomkovicz, "Beyond Secrecy for Secrecy's Sake: Toward an Expanded Vision of the Fourth Amendment Privacy Province," 
Hastings Law Journal 36 (1985): 645-737; Richard G. Wilkins, "Defining the 'Reasonable Expectation of Privacy': An Emerging Tripartite Analysis," Vanderbilt Law Review 40, no. 5 (1987): 1077-1129; Thomas Y. Davies, "Recovering the Original Fourth Amendment," Michigan Law Review 98, no. 3 (1999): 547-750; Orin Kerr, "The Fourth Amendment and New Technologies: Constitutional Myths and the Case for Caution," Michigan Law Review 102, no. 5 (2004): 801-88; Susan Freiwald, "First Principles of Communications Privacy," Stanford Technology Law Review 3 (2007), http:/ /stlr.stanford.edu/pdf/freiwald-first-principles.pdf.

4. See Anslem L. Strauss, Negotiations: Varieties, Contexts, Processes, and Social Order (San Francisco: Jossey-Bass, 1978).

5. Jack Balkin, Cultural Software: A Theory of Ideology (New Haven, CT: Yale University Press, 1999).

6. By "agency" I refer to the actions of individual human agents within certain structures and contexts.

7. Balkin, Cultural Software, 5.

8. Ibid., 14.

9. Ibid., 104.

10. Strauss, Negotiations, 101.

11. See Thomas J. Misa, "Retrieving Sociotechnical Change from Technological Determinism," in Does Technology Drive History? The Dilemma of Technological Determinism, ed. Merritt Roe Smith and Leo Marx (Cambridge, MA: MIT Press, 1994), 115-42.

12. Lewis Coe, The Telegraph: A History of Morse's Invention and Its Predecessors in the United States (Jefferson, NC: McFarland and Company, 2003), 51-65.

13. Paul Starr, The Creation of the Media: Political Origins of Modern Communication (New York: Basic Books, 2004), 178. For a discussion of the relationship between the telegraph and financial speculation, see David Hochfelder, The Telegraph in America, 1832-1920 (Baltimore, MD: Johns Hopkins University Press, 2012), 101-37.

14. See Daniel Solove, Understanding Privacy (Cambridge, MA: Harvard University Press, 2008), 63; and Richard R. John, Network Nation: Inventing American Telecommunications (Cambridge, MA: Harvard/Belknap Press, 2012), 142-44.

15. Anuj C. Desai, "Wiretapping before the Wires: The Post Office and the Birth of Communications Privacy," Stanford Law Review 60, no. 2 (2007): 557. To protect the privacy of messages sent via telegraph, many users developed methods of encryption. See Simon Singh, The Code Book (New York: Anchor Books, 1999), 75.

16. See Oliver, “America’s First Wiretapping Controversy," 216.

17. For a history of the conflict between Western Union and the federal government, see Menahem Blondheim, "Rehearsal for Media Regulation: Congress versus the Telegraph-News Monopoly, 1866-1900," Federal Communications Law Journal 56, no. 3 (2004): 299-328. See also Morris Gray, A Treatise on Communications by Telegraph (1885; repr., Whitefish, MT: Kessinger Publishing, 2008), 115.

18. "The Right to Privacy in Nineteenth Century America," Harvard Law Review 94, no. 8 (1981): 1892, 1901.

19. Samuel Dash, The Intruders: Unreasonable Searches and Seizures from King John to John Ashcroft (New Brunswick, NJ: Rutgers University Press, 2004), 31, 79.

20. Ex parte Jackson, 96 U.S. 727 (1878).

21. Desai, "Wiretapping," 554. 
22. See David J. Seipp, The Right to Privacy in American History (Cambridge, MA: Harvard University Program on Information Resources Policy, 1978), 42.

23. Oliver, “America's First Wiretapping Controversy,” 234.

24. See John, Network Nation, 219.

25. Andre Millard, America on Record: A History of Recorded Sound (Cambridge: Cambridge University Press, 1995), 17-36. See also Edward Long, The Intruders: The Invasion of Privacy by Government (New York: Praeger, 1967), 36.

26. See David Morton, Off the Record: The Technology and Culture of Sound Recording in America (New Brunswick, NJ: Rutgers University Press, 1999), 13-47. 27. A drop loop is the individual line connecting a building to the overhead bundle of telephone cables.

28. Dash, The Eavesdroppers, 314-15.

29. Ibid., 310-18.

30. Wesley MacNeil Oliver, "The Neglected History of Criminal Procedure, 1850-1940,” Rutgers Law Review 62, no. 2 (2010): 460-61.

31. Susan L. Miller, Gender and Community Policing: Walking the Talk (Boston: Northeastern University Press, 1999), 80.

32. Oliver, "The Neglected History," 466-67.

33. See Margaret Lybolt Rosenzweig, "The Law of Wire Tapping," Cornell Law Quarterly 32 (1947): 514.

34. In 1907 the words "universal service" first entered the American policy lexicon, appearing in that year's annual report of AT\&T. That ambition was followed by rapid growth in service to urban and rural areas of the United States. See John, Network Nation, 7, 218.

35. United States Congress, The National Prohibition Act, Titles I and II.

36. The Supreme Court would later write: "During prohibition days, wiretaps were the principal source of information relied upon by the police as the basis for prosecutions" (Berger v. New York, 388 U.S. 46 [1967]).

37. Victor House, "Search and Seizure Limits under the Prohibition Act," New York Times, February 11, 1923, 14.

38. Swire, "Katz Is Dead," 906-7. For a more detailed historical discussion of mere evidence, see William T. Rintala, "The Mere Evidence Rule: Limitations on Seizure under the Fourth Amendment," California Law Review 54, no. 5 (1966): 2099-2122.

39. Craig S. Lerner, "The Reasonableness of Probable Cause," Texas Law Review 81, no. 4 (2003): 951, 986.

40. Oliver, "America's First Wiretapping Controversy," 234-35.

41. See Post, "Federalism."

42. Richard E. Morgan, Domestic Intelligence: Monitoring Dissent in America (Austin: University of Texas Press, 1980), 15-16.

43. Kerr, "The Fourth Amendment," 841-42, emphasis added.

44. The first cases that mention wiretapping by federal agents are Wallace v. United States, 291 F. 972 (6th Cir. 1923), Wolf v. United States, 292 F. 673 (6th Cir. 1923), and Robilio v. United States, 291 F. 975 (6th Cir. 1923).

45. The majority opinion criticized the criminal investigation as "a conspiracy of amazing magnitude.” See Olmstead v. United States, 277 U.S. 438, 455 (1928).

46. For a more thorough discussion of Olmstead v. United States, see Steiker, "Brandeis in Olmstead." Also see Walter F. Murphy, Wiretapping on Trial: A Case Study in the Judicial Process (New York: Random House, 1965). 
47. Olmstead, 277 U.S. at 485.

48. In Berger v. New York the Supreme Court discussed at length the history of telephone surveillance and the Fourth Amendment (388 U.S. at 45-100, and see 56 for a discussion of eavesdropping).

49. Taft wrote, "Congress may of course protect the secrecy of telephone messages by making them, when intercepted, inadmissible in evidence in federal criminal trials, by direct legislation" (Olmstead, 277 U.S. at 465).

50. Samuel D. Warren and Louis D. Brandeis, "The Right to Privacy," Harvard Law Review 4, no. 5 (1890): 195. For a discussion of this article's impact on latenineteenth-century legal debates, see Melvin Urofsky, Louis D. Brandeis: A Life (New York: Random House, 2009), 46-74.

51. Warren and Brandeis, "The Right to Privacy," 195, 201.

52. This would have been the first reference to television in a Supreme Court case, but a law clerk objected to the term, and Brandeis removed it. See Brad Snyder, "The Judicial Genealogy (and Mythology) of John Roberts: Clerkships from Gray to Brandeis to Friendly to Roberts," Ohio State Law Journal 71, no. 6 (2010): 1181-82.

53. For a discussion of the tensions on the Taft Court, see Urofsky, Louis D. Brandeis, 517-617.

54. Olmstead, 277 U.S. at 485 (Brandeis dissenting).

55. Ibid. at 438-39.

56. United States Congress, Communications Act (1934).

57. Communications Act, Title 47, chap. 5, subchap. II, pt. I, § 229.

58. For a detailed history of the FCC's origins, see R. H. Coase, "The Federal Communications Commission," Journal of Law and Economics 2 (October 1959): 1-40.

59. Nardone was actually two decisions, resulting in the same judgment regarding admissibility of evidence. For a discussion of the first (302 U.S. 379 [1937]) and second (308 U.S. 338 [1937]) cases entitled Nardone v. United States and a criticism of the Court decisions, see William P. Rogers, "The Case for Wiretapping," Yale Law Journal 63 (1953): 792-98.

60. Nardone, 302 U.S. at 382.

61. This follows the "fruit of the poisoned tree" doctrine established in Silverthorne Lumber Co. v. United States (251 U.S. 385 [1920]).

62. Nardone, 302 U.S. at 384.

63. See United States Senate Select Committee to Study Governmental Operations with Respect to Intelligence Activities, Intelligence Activities and the Rights of Americans, Final Report (Washington, DC: US Government Printing Office, 1976), bk. 2, 94-755.

64. Charns, Cloak and Gavel, 1-17, 18-35. For a detailed account of the protracted battle between the FCC and FBI on the legality of wiretapping, see Edwardson, "James Lawrence Fly."

65. United States Congress, Office of Technology Assessment, Federal Government Information Technology: Electronic Surveillance and Civil Liberties (Washington, DC: OTACIT-293, 1985), 32.

66. See Athan G. Theoharis and John Stuart Cox, The Boss: J. Edgar Hoover and the Great American Inquisition (Philadelphia: Temple University Press, 1988), $117-32,133-56$.

67. See Theoharis and Cox, The Boss, 133-56, 157-98. 
68. See Paul E. Ceruzzi, Internet Alley: High Technology in Tysons Corner, 19452005 (Cambridge, MA: MIT Press, 2007), 19-42, 43-64.

69. United States Congress, Office of Technology Assessment, Federal Government Information Technology, 32.

70. Ibid.

71. Ibid.

72. For an example of the Eisenhower administration's appetite for wiretapping to combat Communist infiltration of the federal government, see Herbert Brownell, "Public Security and Wire Tapping," Cornell Law Quarterly 39, no. 2 (1953): 195-212.

73. Barton J. Bernstein, "The Road to Watergate and Beyond: The Growth and Abuse of Executive Power since 1940," Law and Contemporary Problems 40, no. 2, special issue on presidential power, pt. 1 (Spring 1976): 58-86.

74. See Garry Wills, Bomb Power: The Modern Presidency and the National Security State (New York: Penguin, 2010), 57, 59-61, 82-83, 98. See also Heidi Kitrosser, "It Came from Beneath the Twilight Zone: Wiretapping and Article II Imperialism," Texas Law Review 88, no. 7 (2010): 1401-34.

75. For a wider discussion, see Ruth S. Cowan, A Social History of American Technology (New York: Oxford University Press, 1997), 93-116.

76. Berger, 388 U.S. at 41.

77. Ibid.

78. Justices Black, Harlan, and White offered dissenting opinions to the court decision.

79. United States v. Rabinowitz, 339 U.S. 56, 68-69 (1950) (Frankfurter dissenting).

80. Katz v. United States, 389 U.S. 352 (1967), emphasis added.

81. Justice Marshall was absent during the case. Justice Black offered the only vote against the decision.

82. Katz, 389 U.S. at 360-62 (Harlan concurring).

83. Anthony G. Amsterdam, "Perspectives on the Fourth Amendment," Minnesota Law Review 58 (1974): 349, 382.

84. James J. Tomkovicz, "Beyond Secrecy for Secrecy's Sake: Toward an Expanded Vision of the Fourth Amendment Privacy Province," Hastings Law Journal 36 (1985): 645, 649.

85. Richard G. Wilkins, "Defining the 'Reasonable Expectation of Privacy': An Emerging Tripartite Analysis," Vanderbilt Law Review 40 (1987): 1077, 1087.

86. Swire, "Katz Is Dead," 904.

87. For a wider discussion of Katz $v$. United States, see the special issue of the UC Davis Law Review dedicated to the fortieth anniversary of the case. See especially Timothy Casey, "Electronic Surveillance and the Right to Be Secure," UC Davis Law Review 41, no. 3 (2008): 977-1033.

88. Katz, 389 U.S. at $350-51$.

89. Warren and Brandeis, "The Right to Privacy," 193.

90. Kerr, "The Fourth Amendment," 823. John M. Junker is also skeptical of Katz's significance ("The Structure of the Fourth Amendment: The Scope of the Protection," Journal of Criminal Law and Justice 79, no. 4 [1989]: 1105, 1125).

91. Berger, 388 U.S. at 112-13 (White dissenting).

92. President's Commission on Law Enforcement and Administration of Justice, The Challenge of Crime in a Free Society (1967), 202-3. 
93. Ibid., 203.

94. Kerr, "The Fourth Amendment," 849.

95. See Omnibus Crime Control and Safe Streets Act (1968) at 2113.

96. Balkin, Cultural Software, 95.

97. Davies, "Recovering," 551.

98. Wayne R. LaFave, quoted in Amsterdam, "Perspectives," 349.

99. Akhil Reed Amar, The Constitution and Criminal Procedure: First Principles (New Haven, CT: Yale University Press, 1998), 1.

100. Ronald J. Allen and Ross M. Rosenberg, "The Fourth Amendment and the Limits of Theory: Local versus General Theoretical Knowledge," St. John's Law Review 72 (1998): 1149.

101. Craig M. Bradley, "Two Models of the Fourth Amendment," Michigan Law Review 83 (1985): 1468.

102. Silas J. Wasserstrom and Louis Michael Seidman, "The Fourth Amendment as Constitutional Theory," Georgetown Law Journal 77 (1988): 19, 29.

103. Jed Rubenfeld, "The End of Privacy," Stanford Law Review 61 (2008): $101,104$.

104. Daniel J. Solove, "Fourth Amendment Pragmatism," Boston College Law Review 51 (2010): 1511, 1514-15.

105. Chapman v. United States, 365 U.S. 618 (1961) (Frankfurter concurring).

106. Interview by Susan Swain with Antonin Scalia, Associate Justice of the United States Supreme Court, in Washington, DC, June 19, 2009, http:// supremecourt.c-span.org/assets/pdf/AScalia.pdf.

107. See Desai, "Wiretapping," 553-54.

108. Oliver Wendell Holmes, The Common Law, in The Collected Works of Justice Holmes: Complete Public Writings and Selected Judicial Opinions of Oliver Wendell Holmes, ed. S. M. Novick (Chicago: University of Chicago Press, 1995), 115.

109. Lawrence Lessig, Code and Other Laws of Cyberspace (New York: Basic Books, 2000), 116.

110. Cass R. Sunstein, "Constitutional Caution," University of Chicago Legal Forum, issue 1996, 361, 363.

111. Rich Haglund, "Applying Pen Register and Trap and Trace Devices to Internet Communications: As Technology Changes, Is Congress or the Supreme Court Best-Suited to Protect Fourth Amendment Expectations of Privacy?," Vanderbilt Journal of Entertainment Law and Practice 5 (2003): 137, 146.

112. Thomas P. Hughes, "Technological Momentum: Hydrogenation in Germany, 1900-1933," Past and Present, August 1969, 106-32. See also Thomas P. Hughes, "Technological Momentum," in Does Technology Drive History? The Dilemma of Technological Determinism, ed. Merritt Roe Smith and Leo Marx (Cambridge, MA: MIT Press, 1994), 101-14. 